\title{
Terpenoids and Coumarins Isolated from the Fruits of Poncirus trifoliata
}

\author{
Guang-Hua Xu, ${ }^{a}$ Jeong-Ah KIM, ${ }^{a}$ So-Young KIM, ${ }^{b}$ Jae-Chun RYu, ${ }^{c}$ Young-Soo KIM, ${ }^{d}$ \\ Sang-Hun JunG, ${ }^{e}$ Mi-Kyeong KIM, ${ }^{f}$ and Seung-Ho LeE* ${ }^{*}$, \\ ${ }^{a}$ College of Pharmacy, Yeungnam University; Gyeongsan, Gyeongsangbuk-do 712-749, Korea: ${ }^{b}$ McArdle Laboratory for \\ Cancer Research, University of Wisconsin at Madison; 1400 University Avenue, Madison, WI 53706 U.S.A.: ${ }^{c}$ Toxicology \\ Labolatory, Korea Institute of Science and Technology; Seoul 130-650, Korea: ${ }^{d}$ College of Medicine, Center for \\ Bioresource and Health, Chungbuk National University; ${ }^{f}$ College of Medicine, Chungbuk National University; Cheongju \\ 361-763, Korea: and ${ }^{e}$ College of Pharmacy, Chungnam National University; Daejeon 305-764, Korea.
}

Received November 16, 2007; accepted March 17, 2008

Four new triterpenes, $21 \alpha$-methylmelianodiol (1), $21 \beta$-methylmelianodiol (2), hispidol A 25-methyl ether (3) and hispidol B 25-methyl ether (4), and a new coumarin, isoschininallylol (5), were isolated from the fruits of Poncirus trifoliata Rafinesque, along with seventeen known compounds. The structures of the new compounds $(1-5)$ were elucidated by interpretation of their spectroscopic data.

Key words Poncirus trifoliata; Rutaceae; triterpene; coumarin

The immature fruits of Poncirus trifoliata RAFInesQue (Rutaceae), Ponciri Fructus, are well acknowledged as a traditional medicine in Eastern Asia, especially for treating allergic diseases. Previously, its crude extracts have exhibited anti-inflammatory, anti-bacterial and anti-mucin releasing activities, ${ }^{1-3)}$ and several coumarin derivatives have been identified as potent antiplatelet constituents. ${ }^{4}$ ) Besides of coumarins, flavonoids, terpenoids and several essential oils have also been reported from this plant. ${ }^{5,6)}$ In this study, five new compounds, $21 \alpha$-methylmelianodiol (1), $21 \beta$ methylmelianodiol (2), hispidol A 25-Me ether (3), hispidol B 25-Me ether (4), and isoschininallylol (5), were isolated from the methanol extract of Ponciri Fructus, as well as seventeen known compounds, including three terpenoids, caryophyllene $\beta$-oxide, 21 $\alpha, 25$-dimethylmelianodiol and $21 \beta, 25$-dimethylmelianodiol; one steroid, $\beta$-sitosterol; nine coumarins, auraptene, isoimperatorin, bergapten, imperatorin, phellopterin, umbelliferone, isoschinilenol, scopoletin and heraclenol 3"-Me ether; two flavonoids, poncirin and naringin; and two phenolic compounds, bis(2-methylheptyl)phthalate and avenalumic acid methyl ester.

\section{Results and Discussion}

Compound 1 was obtained as white powder. A molecular formula of $\mathrm{C}_{31} \mathrm{H}_{50} \mathrm{O}_{5}$ was assigned to $\mathbf{1}$ on the basis of its HR-FAB-MS, ${ }^{13} \mathrm{C}-\mathrm{NMR}$ and DEPT spectral data. The ${ }^{1} \mathrm{H}-$ NMR spectrum of $\mathbf{1}$ (Table 1) displayed characteristic signals for seven tertiary methyl groups $\left(\mathrm{CH}_{3}-18,19,26,27,28,29\right.$, 30 ), one methoxy group, three oxygenated methine protons $(\mathrm{H}-21,23,24)$, one olefinic proton $(\mathrm{H}-7)$, and several over- lapping protons for aliphatic methines and methylenes. Consistent with the ${ }^{1} \mathrm{H}-\mathrm{NMR}$ spectrum of compound $\mathbf{1}$, its ${ }^{13} \mathrm{C}$ NMR spectrum (Table 1) exhibited signals for seven methyl groups, one methoxy group, eight methylenes, eight methines, and seven quaternary carbons. Based on the observed ${ }^{13} \mathrm{C}$-NMR chemical shifts, it was apparent that one saturated ketone (C-3), three oxygenated methine carbons (C-21, C-23, $\mathrm{C}-24)$ and one oxygenated quaternary carbon $(\mathrm{C}-25)$ were present in the molecule of $\mathbf{1}$. All the above-mentioned NMR observation suggested that compound $\mathbf{1}$ is a triterpene possessing one methoxy group. The locations of five methyl groups were assigned at C-4, C-10, C-13, and C-14 on the basis of the following HMBC (Fig. 2) correlations: the proton signals of $\mathrm{CH}_{3}-28$ and $\mathrm{CH}_{3}-29$ with $\mathrm{C}-3, \mathrm{C}-4$, and $\mathrm{C}-5$; $\mathrm{CH}_{3}-18$ with $\mathrm{C}-12, \mathrm{C}-13, \mathrm{C}-14$, and $\mathrm{C}-17$; $\mathrm{CH}_{3}-19$ with $\mathrm{C}-1$, $\mathrm{C}-5$, C-9, and $\mathrm{C}-10 ; \mathrm{CH}_{3}-30$ with $\mathrm{C}-7, \mathrm{C}-8, \mathrm{C}-9$, and $\mathrm{C}-14$. The downfield shift of two methyl groups at $\delta_{\mathrm{H}} 1.24$ and 1.27 suggested the presence of an oxygenated carbon at C-25. Additionally, the $\mathrm{HMBC}$ correlations of the proton signals of $\mathrm{CH}_{3}-26$ and $\mathrm{CH}_{3}-27$ at $\delta_{\mathrm{H}} 1.24$ and 1.27 with $\mathrm{C}-25$ at $\delta_{\mathrm{C}}$ 73.09 were observed. The presence of tetrahydrofuran ring in the side chain was assigned based on the observed correlations in its $2 \mathrm{D}$ NMR $\left({ }^{1} \mathrm{H}-{ }^{1} \mathrm{H}\right.$ COSY, HMQC and HMBC) spectra. The HMBC correlation between a methoxy group at $\delta_{\mathrm{H}} 3.31$ and C-21 at $\delta_{\mathrm{C}} 108.9$ identified the attachment of a methoxy group at $\mathrm{C}-21$. Its side chain possessing tetrahydrofuran ring in compound $\mathbf{1}$ was found to be similar to holstinone $\mathrm{A},{ }^{7)}$ the 21-methoxy analogue of melianodiol. ${ }^{8)}$ To determine the relative configuration at $\mathrm{C}-21$ in compound $\mathbf{1}$, NOE experiment was performed with irradiation at $\delta_{\mathrm{H}} 3.31$.
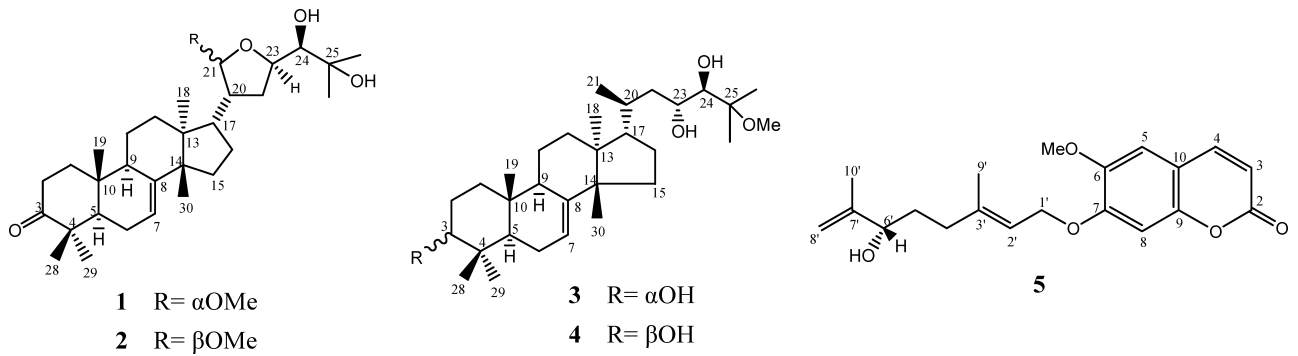

Fig. 1. Chemical Structures of Compounds $\mathbf{1}-\mathbf{5}$ 
Table 1. ${ }^{1} \mathrm{H}$ - and ${ }^{13} \mathrm{C}$-NMR Data for Compounds $\mathbf{1}-\mathbf{4}^{a)}$

\begin{tabular}{|c|c|c|c|c|c|c|c|c|}
\hline \multirow{2}{*}{ Position } & \multicolumn{2}{|r|}{$\mathbf{1}\left(\mathrm{CDCl}_{3}\right)$} & \multicolumn{2}{|r|}{$2\left(\mathrm{CDCl}_{3}\right)$} & \multicolumn{2}{|r|}{3 (pyridine- $d_{5}$ ) } & \multicolumn{2}{|r|}{4 (pyridine- $d_{5}$ ) } \\
\hline & $\delta_{\mathrm{C}}$ & $\delta_{\mathrm{H}}(J$ in $\mathrm{Hz})$ & $\delta_{\mathrm{C}}$ & $\delta_{\mathrm{H}}(J$ in $\mathrm{Hz})$ & $\delta_{\mathrm{C}}$ & $\delta_{\mathrm{H}}(J$ in $\mathrm{Hz})$ & $\delta_{\mathrm{C}}$ & $\delta_{\mathrm{H}}(J$ in $\mathrm{Hz})$ \\
\hline 1 & 38.47 & & 38.52 & & 31.80 & & 37.62 & \\
\hline 2 & 35.06 & $2.23 \mathrm{~m}$ & 35.08 & $2.25 \mathrm{~m}$ & 26.49 & $1.82 \mathrm{~m}$ & 28.62 & $1.85 \mathrm{~m}$ \\
\hline & & $2.74 \mathrm{dt}(14.4,5.4)$ & & $2.75 \mathrm{dt}(14.4,5.4)$ & & $2.00 \mathrm{~m}$ & & $2.01 \mathrm{~m}$ \\
\hline 3 & 216.9 & & 216.8 & & 75.20 & $3.64 \mathrm{brs}$ & 78.32 & $3.45 \mathrm{t}(8.1)$ \\
\hline 4 & 47.86 & & 47.85 & & 37.86 & & 39.57 & \\
\hline 5 & 52.32 & $1.70 \mathrm{~m}$ & 52.41 & $1.71 \mathrm{~m}$ & 44.80 & $2.18 \mathrm{~m}$ & 51.15 & $1.45 \mathrm{~m}$ \\
\hline 6 & 24.32 & $2.07 \mathrm{~m}$ & 24.35 & $2.05 \mathrm{~m}$ & 24.27 & $2.00 \mathrm{~m}$ & 24.43 & $2.02 \mathrm{~m}$ \\
\hline 7 & 118.1 & $5.27 \mathrm{brd}(2.8)$ & 118.1 & $5.28 \mathrm{brd}(2.8)$ & 118.4 & $5.29 \mathrm{br} \mathrm{s}$ & 118.4 & $5.28 \mathrm{br} \mathrm{s}$ \\
\hline 8 & 145.5 & & 145.6 & & 146.3 & & 146.1 & \\
\hline 9 & 48.26 & $2.28 \mathrm{~m}$ & 48.32 & $2.27 \mathrm{~m}$ & 49.04 & $2.46 \mathrm{~m}$ & 49.31 & $2.27 \mathrm{~m}$ \\
\hline 10 & 34.89 & & 34.90 & & 35.08 & & 35.22 & \\
\hline 11 & 17.74 & $1.56 \mathrm{~m}$ & 17.71 & $1.55 \mathrm{~m}$ & 18.30 & $1.56 \mathrm{~m}$ & 18.43 & $1.52 \mathrm{~m}$ \\
\hline 12 & 31.48 & & 31.08 & & 34.27 & & 34.37 & \\
\hline 13 & 43.60 & & 43.50 & & 43.71 & & 43.76 & \\
\hline 14 & 50.94 & & 50.76 & & 51.45 & & 51.46 & \\
\hline 15 & 34.31 & & 34.18 & & 34.11 & & 34.19 & \\
\hline 16 & 27.38 & & 27.31 & & 28.72 & & 28.81 & \\
\hline 17 & 50.27 & $1.73 \mathrm{~m}$ & 44.98 & $1.98 \mathrm{~m}$ & 54.22 & $1.65 \mathrm{~m}$ & 54.28 & $1.66 \mathrm{~m}$ \\
\hline 18 & 22.58 & $0.98 \mathrm{~s}$ & 23.25 & $0.98 \mathrm{~s}$ & 21.93 & $0.78 \mathrm{~s}$ & 22.11 & $0.78 \mathrm{~s}$ \\
\hline 19 & 12.71 & $0.82 \mathrm{~s}$ & 12.72 & $0.81 \mathrm{~s}$ & 13.38 & $0.83 \mathrm{~s}$ & 13.45 & $0.86 \mathrm{~s}$ \\
\hline 20 & 47.67 & $1.98 \mathrm{~m}$ & 46.28 & $1.98 \mathrm{~m}$ & 34.47 & $1.71 \mathrm{~m}$ & 34.53 & $1.73 \mathrm{~m}$ \\
\hline 21 & 108.9 & 4.75 br s & 104.9 & $4.71 \mathrm{brs}$ & 19.52 & $1.10 \mathrm{~d}(5.6)$ & 19.62 & $1.12 \mathrm{~d}(5.8)$ \\
\hline 22 & 33.76 & $1.90 \mathrm{~m}$ & 31.57 & $1.90 \mathrm{~m}$ & 42.87 & $2.19 \mathrm{~m}$ & 42.95 & $2.18 \mathrm{~m}$ \\
\hline 23 & 76.72 & $4.20 \mathrm{dt}(2.9,8.3)$ & 78.85 & $4.40 \mathrm{dt}(2.8,8.4)$ & 68.21 & $4.42 \mathrm{~m}$ & 68.13 & $4.41 \mathrm{~m}$ \\
\hline 24 & 75.34 & $3.22 \mathrm{br} \mathrm{s}$ & 76.52 & $3.31 \mathrm{brs}$ & 76.65 & $3.63 \mathrm{~s}$ & 76.73 & $3.65 \mathrm{~s}$ \\
\hline 25 & 73.09 & & 72.92 & & 78.67 & & 78.75 & \\
\hline 26 & 26.33 & $1.24 \mathrm{~s}$ & 26.30 & $1.22 \mathrm{~s}$ & 22.48 & $1.39 \mathrm{~s}$ & 22.58 & $1.41 \mathrm{~s}$ \\
\hline 27 & 26.43 & $1.27 \mathrm{~s}$ & 26.38 & $1.24 \mathrm{~s}$ & 20.73 & $1.41 \mathrm{~s}$ & 20.82 & $1.43 \mathrm{~s}$ \\
\hline 28 & 21.55 & $1.09 \mathrm{~s}$ & 21.53 & $1.09 \mathrm{~s}$ & 22.11 & $0.94 \mathrm{~s}$ & 15.58 & $1.09 \mathrm{~s}$ \\
\hline 29 & 24.46 & $1.01 \mathrm{~s}$ & 24.48 & $1.01 \mathrm{~s}$ & 28.65 & $1.14 \mathrm{~s}$ & 28.32 & $1.15 \mathrm{~s}$ \\
\hline 30 & 27.26 & $0.99 \mathrm{~s}$ & 27.41 & $1.00 \mathrm{~s}$ & 27.44 & $0.99 \mathrm{~s}$ & 27.47 & $0.98 \mathrm{~s}$ \\
\hline $\mathrm{MeO}-21$ & 55.62 & $3.31 \mathrm{~s}$ & 55.17 & $3.31 \mathrm{~s}$ & & & & \\
\hline $\mathrm{MeO}-25$ & & & & & 49.17 & $3.20 \mathrm{~s}$ & 49.26 & $3.22 \mathrm{~s}$ \\
\hline
\end{tabular}

a) ${ }^{1} \mathrm{H}$ - and ${ }^{13} \mathrm{C}-\mathrm{NMR}$ spectra were acquired at 250 and $63 \mathrm{MHz}$, respectively; TMS was used as internal standard; assignments were based on ${ }^{1} \mathrm{H}-{ }^{1} \mathrm{H} \mathrm{COSY}$, $\mathrm{HMQC}$, $\mathrm{HMBC}$ and NOESY spectra.

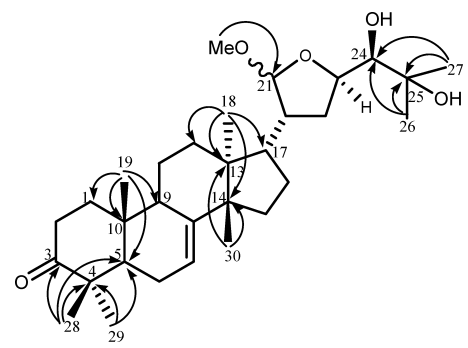

Fig. 2. Selected HMBC Correlations of $\mathbf{1}$ and $\mathbf{2}$

In NOE experiment, irradiation of the OMe-21 resonance at $\delta_{\mathrm{H}} 3.31$ gave an enhancement of the $\mathrm{H}-23$ signal at $\delta_{\mathrm{H}} 4.20$ suggesting the relative configuration of a methoxy group at $\mathrm{C}-21$ is $\alpha$ for $\mathbf{1}$. The absolute configuration at C-24 for $\mathbf{1}$ was determined by comparison the NMR spectral data with limonoid melianodiol and limonoid 24-epi-melianodiol. ${ }^{8)}$ Based on the above spectral evidences, the structure of 1 was elucidated as $21 \alpha$-methylmelianodiol $(21 R, 23 R)$-epoxy- $24 S$ hydroxy-21 $\alpha$-methoxytirucalla-7-en-3-one.

Compound 2 was isolated as a white powder. The molecular formula of $\mathrm{C}_{31} \mathrm{H}_{50} \mathrm{O}_{5}$, the same as that of $\mathbf{1}$, was determined for 2 by HR-FAB-MS, ${ }^{13} \mathrm{C}-\mathrm{NMR}$ and DEPT spectral data. Both the ${ }^{1} \mathrm{H}$ - and ${ }^{13} \mathrm{C}-\mathrm{NMR}$ spectroscopic data of compound 2 (Table 1) were closely comparable to those of $\mathbf{1}$, suggesting it is also a triterpene possessing one methoxy group. The gross structure of compound $\mathbf{2}$ was assigned as the same as that of compound $\mathbf{1}$ based on the observed correlations in its $2 \mathrm{D}$ NMR $\left({ }^{1} \mathrm{H}-{ }^{1} \mathrm{H}\right.$ COSY, HMQC and HMBC) spectra. The same correlations as that of $\mathbf{1}$ were observed in HMBC spectrum of 2 (Fig. 2). However, the signals for C-17 and C-21 were relatively upfield at $\delta_{\mathrm{C}} 44.98$ and 104.9 , while the signal for $\mathrm{C}-23$ was downfield at $\delta_{\mathrm{C}} 78.85$, suggesting $\gamma$-gauche effect of the oxygenated substituent on $\mathrm{C}-21 \beta .{ }^{9)}$ Additionally, in contrast to compound 1, an enhancement of the $\mathrm{H}-23$ signal at $\delta_{\mathrm{H}} 4.20$ with irradiation of the OMe-21 resonance at $\delta_{\mathrm{H}} 3.31$ was not observed in its NOE experiment. Therefore, the relative configuration of the methoxy group at C-21 in compound $\mathbf{2}$ was assigned as a $21 \beta$. Based on the above spectral evidences, the structure of 2 was elucidated as $21 \beta$-methylmelianodiol $(21 S, 23 R)$-epoxy-24S-hydroxy-21 $\beta$-methoxytirucalla-7-en-3-one.

Compounds 3 and 4 displayed very similar ${ }^{1} \mathrm{H}-$ and ${ }^{13} \mathrm{C}$ NMR spectra, and the same molecular formula, $\mathrm{C}_{31} \mathrm{H}_{54} \mathrm{O}_{4}$, as established for both substances based on their HR-FAB-MS, ${ }^{13} \mathrm{C}-\mathrm{NMR}$ and DEPT spectral data. Their ${ }^{1} \mathrm{H}$-NMR spectra exhibited the typical resonances for a seven tertiary methyl groups, one methoxy group, three oxygenated methine protons, and one olefinic proton, together with one secondary methyl group. These signals were characteristic of the tiru- 


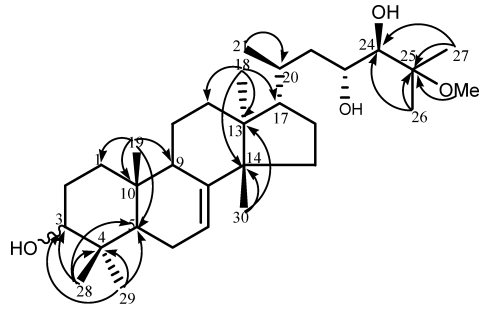

Fig. 3. Selected HMBC Correlations of $\mathbf{3}$ and $\mathbf{4}$

call-7-ene triterpene skeleton with a 3-hydroxy group. ${ }^{10)}$ The ${ }^{1} \mathrm{H}$ - and ${ }^{13} \mathrm{C}$-NMR spectroscopic data suggested that compounds $\mathbf{3}$ and $\mathbf{4}$ have the same gross structure, which was found to be similar to hispidol $\mathrm{A}$ and hispidol $\mathrm{B},{ }^{11,12)}$ except for the presence of a new methoxy group at $\delta_{\mathrm{H}} 3.20$. The HMBC correlations of methoxy group with $\mathrm{C}-25$ and two methyl groups, $\mathrm{H}-26$ and $\mathrm{H}-27$ with $\mathrm{C}-25$ indicated the location of methoxy group is at C-25 (Fig. 3). Although compounds $\mathbf{3}$ and $\mathbf{4}$ have the same gross structure based on the interpretation of their NMR data, differences of NMR chemical shifts were observed in ring A, as well as the splitting pattern of $\mathrm{H}-3$, suggesting compounds 3 and $\mathbf{4}$ were epimeric at C-3 (Table 1). While a broad singlet for H-3 signal at 3.64 was indicating the axial $3-\mathrm{OH}$ in compound $3, \mathrm{H}-3$ signal as a doublet of doublets at $3.45(J=11.0,5.1 \mathrm{~Hz})$ was indicating equatorial $3-\mathrm{OH}$ in compound $4 .^{13)}$ Based on the above spectral evidences, the structures of $\mathbf{3}$ and $\mathbf{4}$ were elucidated as $(3 R, 23 S, 24 R)-25$-methoxytirucalla-7-ene-3,23,24-triol and $(3 S, 23 S, 24 R)-25$-methoxytirucalla-7-ene-3,23,24-triol, respectively.

Compound 5 was obtained as brown gum and its molecular formula, $\mathrm{C}_{20} \mathrm{H}_{24} \mathrm{O}_{5}$, was established from HR-FAB-MS, ${ }^{13} \mathrm{C}-\mathrm{NMR}$ and DEPT spectral data. The UV absorptions at 348, 298 and $241 \mathrm{~nm}$ suggested a 7-oxygenated coumarin skeleton. ${ }^{14)}$ In the ${ }^{1} \mathrm{H}-\mathrm{NMR}$ spectrum of $\mathbf{5}$, the characteristic signals of a 6,7-disubstituted coumarin were apparent, with doublets at $\delta_{\mathrm{H}} 6.27(1 \mathrm{H}, \mathrm{d}, J=9.5 \mathrm{~Hz}, \mathrm{H}-3)$ and $7.61(1 \mathrm{H}, \mathrm{d}$, $J=9.5 \mathrm{~Hz}, \mathrm{H}-4)$, two aromatic signal at $\delta_{\mathrm{H}} 6.82(1 \mathrm{H}, \mathrm{s}, \mathrm{H}-5)$ and $6.79(1 \mathrm{H}, \mathrm{s}, \mathrm{H}-8)$, and one methoxy signal at $\delta_{\mathrm{H}} 3.88$ $\left(3 \mathrm{H}, \mathrm{s}, \mathrm{OCH}_{3}-6\right){ }^{15)}$ The location of methoxy group was assigned to C- 6 based on the HMBC correlation between a methoxyl signal at $\delta_{\mathrm{H}} 3.88$ and C-6 at $\delta_{\mathrm{C}} 146.6$ (Fig. 4). In addition, its ${ }^{1} \mathrm{H}-\mathrm{NMR}$ spectrum showed eight more signals due to a terminal methylene proton $\left(\delta_{\mathrm{H}} 4.90,4.81\right)$, a methine proton $\left(\delta_{\mathrm{H}} 4.02\right)$, three methylene protons $\left(\delta_{\mathrm{H}} 4.67\right.$, $2.11,1.66)$, one olefinic proton $\left(\delta_{\mathrm{H}} 5.49\right)$, and two vinylic methyl protons $\left(\delta_{\mathrm{H}} 1.75,1.70\right)$. On the basis of the observed HMQC correlations, these signals were found to correspond to the ${ }^{13} \mathrm{C}$-NMR signals for the terpenyl side-chain, which is very similar to those of schininallylol. ${ }^{16)}$ The HMBC correlation between $\mathrm{H}-1^{\prime}$ at $\delta_{\mathrm{H}} 4.67$ and $\mathrm{C}-7$ at $\delta_{\mathrm{C}} 151.9$ indicated the location of the terpenyl side-chain at C-7. Since the absolute configuration of analogue 7-(6R-hydroxy-3,7-dimethyl-2,7-octadienyl)oxy coumarin was determined as $R$ and showed a positive optical rotation, $\left.{ }^{17}\right)$ whereas $7-(6 S$-hydroxy-3,7-dimethyl-2,7-octadienyl)oxy-8-methoxy coumarin displayed a negative value, ${ }^{16)}$ the stereochemistry at C- 6 ' of 5 was assigned as $S$ configuration by its negative optical rotation. Thus, the structure of $\mathbf{5}$ was elucidated as 7-(6S-hydroxy-3,7-dimethyl-2,7-octadienyl)oxy-6-methoxy coumarin

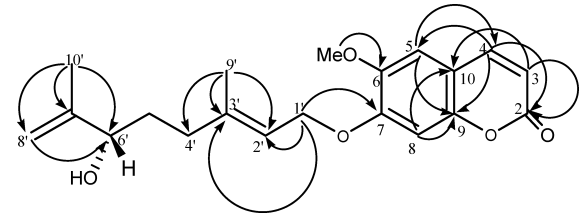

Fig. 4. Selected HMBC Correlations of 5

and named as isoschininallylol.

Other known compounds obtained in this study, $21 \alpha, 25$ dimethylmelianodiol, ${ }^{18)} 21 \beta, 25$-dimethylmelianodiol, ${ }^{18)}$ caryophyllene $\beta$-oxide, ${ }^{19)} \beta$-sitosterol, ${ }^{20)}$ auraptene, ${ }^{21)}$ isoimperatorin, ${ }^{22)}$ bergapten, ${ }^{23)}$ imperatorin, ${ }^{23)}$ phellopterin, ${ }^{24)}$ umbelliferone, ${ }^{24)}$ isoschinilenol, ${ }^{25)}$ scopoletin, ${ }^{26)}$ heraclenol $3 "-\mathrm{Me}$ ether, ${ }^{27,28)}$ poncirin, ${ }^{29)}$ naringin, ${ }^{30)}$ bis(2-methylheptyl)phthalate, ${ }^{31)}$ and avenalumic acid methyl ester, ${ }^{32)}$ were identified by comparing their physical and spectroscopic data with the published values.

\section{Experimental}

General Experimental Procedures Optical rotations were measured using a JASCO DIP-1000 (Tokyo, Japan) automatic digital polarimeter. FTIR spectra were recorded on a JASCO FT-IR 300E spectrophotometer, and UV spectra on a JASCO V-550 spectrophotometer. The NMR spectra were recorded on Bruker $250 \mathrm{MHz}$ (DMX 250) spectrometer using Bruker's standard pulse program, and chemical shifts were reported in ppm downfield from TMS. The HR-FAB mass spectra were recorded on JMS-700 mass spectrometer (JEOL, Japan). Column chromatography was carried out on Merck silica gel (70 - 230 mesh) and Merck Lichroprep RP-18 gel (40$63 \mu \mathrm{m})$. TLC was performed on aluminum plates precoated with Kieselgel $60 \mathrm{~F}_{254}$ (Merck). All other chemicals and solvents were analytical grade and used without further purification.

Plant Material Dried fruits of Poncirus trifoliata RAFINESQue were purchased in September 2003 from a folk medicine market "Yak-ryong-si" in Daegu, South Korea.

Extraction and Isolation The dried fruits of $P$. trifoliata RAFINESQUE $(10 \mathrm{~kg})$ were extracted three times with $100 \% \mathrm{MeOH}$ at room temperature for several days. The $\mathrm{MeOH}$ solution was concentrated under the reduced pressure to give a residue $(500 \mathrm{~g})$ and it was partitioned between $\mathrm{H}_{2} \mathrm{O}$ and $\mathrm{CH}_{2} \mathrm{Cl}_{2}$. The $\mathrm{CH}_{2} \mathrm{Cl}_{2}$ extract $(160 \mathrm{~g})$ was loaded on a silica gel column $(80 \times 12 \mathrm{~cm})$ and eluted with $n$-hexane/EtOAc $(10: 0,9: 1,8: 2,7: 3,6: 4$, $5: 5,4: 6,3: 7,2: 8,1: 9,0: 10$, each 41$)$ in a gradient mode to give 10 fractions (PF1-10). The fraction PF7 (5.9 g) was chromatographed on a silica gel column $(70 \times 6 \mathrm{~cm})$ and eluted with $\mathrm{CH}_{2} \mathrm{Cl}_{2} /$ acetone $(9: 1,8: 2,7: 3,6: 4$, $5: 5,3: 7$, each 41) to give 7 fractions (PF71-7). The fraction PF73 was rechromatographed on a silica gel column $(50 \times 3.5 \mathrm{~cm})$ and eluted with $n$ hexane/EtOAc $(4: 6,5: 5,6: 4,7: 3$, each 31$)$ in a gradient mode to give 6 fractions PF731-6, the fraction PF732 was rechromatographed over a C-18 reverse-phase column $(50 \times 4 \mathrm{~cm})$ eluting with $\mathrm{MeOH} / \mathrm{H}_{2} \mathrm{O}(4: 6,5: 5,6: 4$, $7: 3$, each 31$)$ to afford $1(20 \mathrm{mg})$ and $2(5 \mathrm{mg})$, respectively. The fraction PF75 was re-chromatographed on a silica gel column $(50 \times 3.5 \mathrm{~cm})$ and eluted with $n$-hexane/EtOAc $(4: 6,6: 4,8: 3$, each 31$)$ in a gradient mode to give 4 fractions PF751-4, the fraction PF752 was rechromatographed over a C-18 reverse-phase column $(50 \times 3 \mathrm{~cm})$ eluting with $\mathrm{MeOH} / \mathrm{H}_{2} \mathrm{O}(2: 8,4: 6$, $6: 4,7: 3$, each 31$)$ to afford $3(15 \mathrm{mg})$ and $4(4 \mathrm{mg})$, respectively. The fraction PF9 $(13.5 \mathrm{~g})$ was chromatographed on a silica gel column $(70 \times 6 \mathrm{~cm})$ and eluted with $\mathrm{CH}_{2} \mathrm{Cl}_{2} /$ acetone $(98: 2,96: 4,94: 6,92: 8,90: 10$, each 41$)$ to give 5 fractions (PF91-5). The fraction PF92 was chromatographed on a silica gel column $(60 \times 5 \mathrm{~cm})$ and eluted with $n$-hexane/EtOAc $(95: 5,9: 1$, $8: 2,7: 3,6: 4$, each 41) in a gradient mode to give 5 fractions (PF921-5), the fraction PF923 was rechromatographed over a C-18 reverse-phase column $(50 \times 4 \mathrm{~cm})$ eluting with $\mathrm{MeOH} / \mathrm{H}_{2} \mathrm{O}(2: 8,4: 6,6: 4$, each 31$)$ to afford $5(10 \mathrm{mg})$.

$21 \alpha$-Methylmelianodiol (1): White powder; $[\alpha]_{\mathrm{D}}^{18}-98.4^{\circ} \quad(c=0.1$, $\left.\mathrm{CHCl}_{3}\right) ; \mathrm{UV}\left(\mathrm{CHCl}_{3}\right) \lambda_{\max }(\log \varepsilon) 241(2.99) \mathrm{nm} ; \mathrm{IR}(\mathrm{KBr}) v_{\max } 3505,2953$, $1707,1468,1386,1099,1037 \mathrm{~cm}^{-1}$; ${ }^{1} \mathrm{H}-\mathrm{NMR}\left(250 \mathrm{MHz}, \mathrm{CDCl}_{3}\right)$ and ${ }^{13} \mathrm{C}-$ NMR ( $63 \mathrm{MHz}, \mathrm{CDCl}_{3}$ ), see Table 1; HR-FAB-MS (positive ion mode) $\mathrm{m} / \mathrm{z}$ : $503.3737[\mathrm{M}+\mathrm{H}]^{+}\left(\right.$Calcd for $\left.\mathrm{C}_{31} \mathrm{H}_{51} \mathrm{O}_{5}, 503.3738\right)$.

$21 \beta$-Methylmelianodiol (2): White powder; $[\alpha]_{\mathrm{D}}^{18}-12.9^{\circ}\left(c=0.1, \mathrm{CHCl}_{3}\right)$; $\mathrm{UV}\left(\mathrm{CHCl}_{3}\right) \lambda_{\max }(\log \varepsilon) 242(3.01) \mathrm{nm}$; IR (KBr) $v_{\max } 3444,2952,1707$, 
1467, $1385,1093 \mathrm{~cm}^{-1} ;{ }^{1} \mathrm{H}-\mathrm{NMR} \quad\left(250 \mathrm{MHz}, \mathrm{CDCl}_{3}\right)$ and ${ }^{13} \mathrm{C}-\mathrm{NMR}$ $\left(63 \mathrm{MHz}, \mathrm{CDCl}_{3}\right.$ ), see Table 1; HR-FAB-MS (positive ion mode) $\mathrm{m} / \mathrm{z}$ : $503.3737[\mathrm{M}+\mathrm{H}]^{+}\left(\right.$Calcd for $\left.\mathrm{C}_{31} \mathrm{H}_{51} \mathrm{O}_{5}, 503.3738\right)$.

Hispidol A 25-Me Ether (3): White powder; $[\alpha]_{\mathrm{D}}^{18}-74.3^{\circ}(c=0.1$, $\left.\mathrm{CHCl}_{3}\right)$; UV $\left(\mathrm{CHCl}_{3}\right) \lambda_{\text {max }}(\log \varepsilon) 241(3.16) \mathrm{nm}$; IR (KBr) $v_{\max } 3443,2933$, $1467,1385,1131,1062 \mathrm{~cm}^{-1}$; ${ }^{1} \mathrm{H}-\mathrm{NMR}\left(250 \mathrm{MHz}\right.$, pyridine- $\left.d_{5}\right)$ and ${ }^{13} \mathrm{C}-$ NMR (63 MHz, pyridine- $d_{5}$ ), see Table 1; HR-FAB-MS (positive ion mode) $m / z: 491.4100[\mathrm{M}+\mathrm{H}]^{+}\left(\right.$Calcd for $\left.\mathrm{C}_{31} \mathrm{H}_{55} \mathrm{O}_{4}, 491.4102\right)$.

Hispidol B 25-Me Ether (4): White powder; $[\alpha]_{\mathrm{D}}^{18}-65.5^{\circ}(c=0.1$, $\left.\mathrm{CHCl}_{3}\right)$; UV $\left(\mathrm{CHCl}_{3}\right) \lambda_{\max }(\log \varepsilon) 243(3.20) \mathrm{nm}$; IR (KBr) $v_{\max } 3414,2951$, $1467,1384,1152,1070 \mathrm{~cm}^{-1}$; ${ }^{1} \mathrm{H}-\mathrm{NMR}\left(250 \mathrm{MHz}\right.$, pyridine- $\left.d_{5}\right)$ and ${ }^{13} \mathrm{C}-$ NMR ( $63 \mathrm{MHz}$, pyridine- $d_{5}$ ), see Table 1; HR-FAB-MS (positive ion mode) $m / z: 491.4100[\mathrm{M}+\mathrm{H}]^{+}\left(\right.$Calcd for $\left.\mathrm{C}_{31} \mathrm{H}_{55} \mathrm{O}_{4}, 491.4102\right)$.

Isoschininallylol (5): Brown gum; $[\alpha]_{\mathrm{D}}^{18}-13.0^{\circ}\left(c=0.1, \mathrm{CHCl}_{3}\right)$; UV $\left(\mathrm{CHCl}_{3}\right) \lambda_{\max }(\log \varepsilon) 348$ (3.96), 298 (3.65), $241(3.90) \mathrm{nm}$; IR $\left(\mathrm{CHCl}_{3}\right) v_{\max }$ $3425,1700 \mathrm{~cm}^{-1} ;{ }^{1} \mathrm{H}-\mathrm{NMR}\left(250 \mathrm{MHz}, \mathrm{CDCl}_{3}\right) \delta: 7.61(1 \mathrm{H}, \mathrm{d}, J=9.5 \mathrm{~Hz}, \mathrm{H}-$ 4), $6.82(1 \mathrm{H}, \mathrm{s}, \mathrm{H}-5), 6.79(1 \mathrm{H}, \mathrm{s}, \mathrm{H}-8), 6.27(1 \mathrm{H}, \mathrm{d}, J=9.5 \mathrm{~Hz}, \mathrm{H}-3), 5.49$ $\left(1 \mathrm{H}, \mathrm{t}, J=6.4 \mathrm{~Hz}, \mathrm{H}-2^{\prime}\right), 4.90\left(1 \mathrm{H}, \mathrm{s}, \mathrm{H}-8 \mathrm{a}^{\prime}\right), 4.81\left(1 \mathrm{H}, \mathrm{s}, \mathrm{H}-8 \mathrm{~b}^{\prime}\right), 4.67(2 \mathrm{H}$, d, $\left.J=6.4 \mathrm{~Hz}, \mathrm{H}-1^{\prime}\right), 4.02\left(1 \mathrm{H}, \mathrm{t}, J=6.5 \mathrm{~Hz}, \mathrm{H}-6^{\prime}\right), 3.88(3 \mathrm{H}, \mathrm{s}, 6-\mathrm{OMe}), 2.11$ (2H, m, H-4') 1.75 (3H, s, H-9'), 1.70 (3H, s, H-10'), 1.66 (2H, m, H-5'); ${ }^{13} \mathrm{C}-\mathrm{NMR}\left(63 \mathrm{MHz}, \mathrm{CDCl}_{3}\right.$ ) $\delta: 161.5$ (C-2), $151.9(\mathrm{C}-7), 149.8$ (C-9), 147.2 (C-7'), 146.6 (C-6), 143.3 (C-4), 141.8 (C-3'), 118.6 (C-2'), 113.3 (C-3), 111.3 (C-10), $111.2\left(\mathrm{C}-8^{\prime}\right), 107.9$ (C-5), 101.1 (C-8), 75.37 (C-6'), 66.19 (C-1'), 56.30 (6-OMe), 35.40 (C-4'), $32.62\left(\mathrm{C}-5^{\prime}\right), 17.52$ (C-10') $17.00(\mathrm{C}-$ $9^{\prime}$ ); HR-FAB-MS (positive ion mode) $m / z: 345.1702[\mathrm{M}+\mathrm{H}]^{+}($Calcd for $\left.\mathrm{C}_{20} \mathrm{H}_{25} \mathrm{O}_{5}, 345.1703\right)$.

Acknowledgements This work was supported by the grant (00-PJ2PG1-CD02-0003) of the Good Health R\&D Project, Ministry of Health \& Welfare, R.O.K.

\section{References}

1) Shin T. Y., Oh J. M., Choi B. J., Park W. H., Kim C. H., Jun C. D., Kim S. H., Toxicol. in Vitro, 20, 1071-1076 (2006).

2) Youn W. G., Kim D. H., Kim N. J., Hong N. D., Yakhak Hoeji., 36, $548-555(2001)$

3) Lee C. J., Lee J. H., Seok J. H., Hur G. M., Park J. S., Bae S. H., Lim J. H., Park Y. C., Phytother. Res., 18, 301-305 (2004).

4) Chen I. S., Chang C. T., Sheen W. S., Teng C. M., Tsai I. L., Duh C. Y., Ko F. N., Phytochemistry, 41, 525-530 (1996).

5) Guiotto A., Rodighiero P., Pastorini G., Celon E., Phytochemistry, 16, 1257-1260 (1977).

6) Kim T. J., No J. Y., Ko J. S., Rhee J. S., Analytical Science \& Technology, 2, 301-307 (1989).

7) Mulholland D. A., Monkhe T. V., Taylor D. A. H., Rajab M. S., Phytochemistry, 52, 123-126 (1999).

8) Puripattanavong J., Weber S., Brecht V., Frahm A. W., Planta Med., 66, 740-745 (2000)

9) Nakanishi T., Inada A., Nishi M., Miki T., Hino R., Fujiwara T., Chem
Lett., 1, 69-72 (1986).

10) Benosman A., Richomme P., Bruneton J., Sevenet T., Perromat G., Hadi A. H. A., Phytochemistry, 40, 1485-1487 (1995).

11) Jolad S. D., Hoffman J. J., Schram R. H., Cole J. R., Tempesta M. S., Bates R. B., J. Org. Chem., 46, 4085-4088 (1981).

12) Arisawa M., Fujita A., Morita N., Cox P. J., Howie R. A., Cordell G. A. Phytochemistry, 26, 3301-3303 (1987).

13) Majumder P. L., Maiti R. N., Panda S. K., Mal D., Raju M. S., Wenkert E., J. Org. Chem., 44, 2811-2842 (1979).

14) Chen J. J., Huang S. Y., Duh C. Y., Chen I. S., Wang T. C., Fang H. Y., Planta Med., 72, 935-938 (2006).

15) Kwak J. H., Lee K. B., Schmitz F. J., J. Nat .Prod., 64, 1081-1083 (2001).

16) Chen I. S., Lin Y. C., Tsai I. L., Teng C. M., Ko F. N., Ishikawa T., Ishii H., Phytochemistry, 39, 1091-1097 (1995).

17) Masuda T., Muroya Y., Nakatani N., Phytochemistry, 31, 1363-1366 (1992).

18) Biavatti M. W., Vieira P. C., Da Silva M. F., Fernandes J. B., Albuquerque S., J. Nat. Prod., 65, 562-565 (2002).

19) Kubo I., Muroi H., Kubo A., Chaudhuri S. K., Sanchez Y., Ogura T., Planta Med., 60, 218-221 (1994).

20) Umlauf D., Zapp J., Becker H., Adam K. P., Phytochemistry, 65 $2463-2470$ (2004).

21) Nakatani N., Yamada Y., Fuwa H., Agric. Biol. Chem., 51, 419-423 (1987).

22) Fujioka T., Furumi K., Fujii H., Okabe H., Mihashi K., Nakano Y., Matsunaga H., Katano M., Mori M., Chem. Pharm. Bull., 47, 96-100 (1999).

23) Bergendorff O., Dekermendjian K., Nielsen M., Shan R., Witt R., Ai J., Sterner O., Phytochemistry, 44, 1121-1124 (1997).

24) Kong L. Y., Li Y., Min Z. D., Li X., Zhu T. R., Phytochemistry, 41, 1423-1426 (1996).

25) Tsai I. L., Lin W. Y., Teng C. M., Ishikawa T., Doong S. L., Huang M. W., Chen Y. C., Chen, I. S., Planta Med., 66, 618 - 623 (2000).

26) Ito C., Furukawa H., Chem. Pharm. Bull., 35, 4277-4285 (1987).

27) Tada Y., Shikishima Y., Takaishi Y., Shibata H., Higuti T., Honda G.., Ito M., Takeda Y., Kodzhimatov O. K., Ashurmetov O., Ohmoto Y., Phytochemistry, 59, 649-654 (2002).

28) Baba K., Matsuyama Y., Fukumoto M., Kozawa M., Yakugaku Zasshi, 103, 1091-1095 (1983).

29) Kim D. H., Bae E. A., Han M. J., Biol. Pharm. Bull., 22, 422-424 (1999).

30) Akiyama T., Yamada M., Yamada T., Maitani T., Biosci. Biotechnol. Biochem., 64, 2246-2249 (2000).

31) Cakir A., Mavi A., Yildirim A., Duru M. E., Harmandar M., Kazaz C., J. Ethnopharmacol., 87, 73-83 (2003).

32) Ishihara A., Ohtsu Y., Iwamura H., Phytochemistry, 50, 237-242 (1999). 